\title{
HUBUNGAN KESUBURAN TANAH DENGAN PRODUKTIVITAS TANAMAN
}

\author{
Asmar, Amrizal Saidi, dan Masliyunas \\ J urusan Tanah F akultas Pertanian U niversitas Andalas
}

\begin{abstract}
A research about relationship between soil properties and crop yield was conducted in Pandai Sikek, Tanah Datar Region, center for cabbage and carrot production, West Sumatra in 2004 and 2005. Soil samples were collected from rainfed paddy soils by purposive random sampling. Soil samples were analyzed in Soil Laboratory, Agriculture Faculty and Agriculture Polytechnique Laboratory, Andalas University. Several soil physical properties analysed were soil bulk density and total soil pores by using gravimetric method, permeability with de Boodt method, soil water content at several $\mathrm{pF}$ values using pressure plate apparatus, and soil strength by using penetrometer. Soil chemical parameters analysed were soil pH using pH-meter, organic-C using Walkley and Black, available $\mathrm{P}$ using Bray II, and cation exchange capacity using NH4-leaching at pH 7.0, and $\mathrm{N}$-total using Kjehdhal method. Crop productions were sampled from a $3 \times 3 \mathrm{~m}^{2}$ of soil sampling area. The result showed that soils planted by cabbage and carnot had good soil physical properties, such as having balanced pore size distribution. The chemical properties of the soils were good as well, except N, K- and Ca-exchangeable which were very low. The other soil properties were quite good. Soil physical properties gave different response on both crops. Carrots were more response aeration pore and soil organic matter content, then cabbage was more response on BV, TSP, and slow drainage pores. While soil chemical properties did not give significant response. Both crops responded on Ca, but cabbage was more response on N-total, and carrot on CEC and saturated cation
\end{abstract}

Key Words: Soil Physical Properties, Soil Fertility, Crop Productivity

\section{PENDAHULUAN}

Tanah merupakan sumberdaya alam yang sangat penting dalam menghasilkan bahan makanan dan serat. Produktivitas tanah dalam menghasilkan bahan makanan dan serat tersebut ditentukan oleh tingkat kesuburan dari tanah tersebut. Salah satu tanah yang banyak diusahakan untuk menghasilkan tanaman hortikultura seperti tanaman sayuran dan buahan di Sumatera Barat adalah tanah yang berasal dari bahan induk abu vulkanis dari letusan gunung api, yaitu Andisol. Andisol merupakan tanah yang banyak mengandung bahan-bahan mineral yang subur dan umumnya mempunyai produktivitas yang tinggi. Namun dengan penggunaan lahan yang dilakukan tenus menerus, maka proses degradasi akan berjalan cepat sehingga akan menurunkan produktivitas tanahnya terutama disebabkan oleh erosi. Disamping itu, penggunaan lahan yang kurang sesuai dengan kaedah-kaedah konservasi tanah dan bertani pada lahan miring juga akan mengakibatkan cepat menurunnya produktivitas tanah tersebut (Saidi. 1995).

Kehilangan produktivitas tanah sering diakibatkan oleh pendangkalan tanah atau perubahan lapisan bawah yang tidak menyenangkan untuk pertumbuhan akar (Pierce, Larson, Dowdy, dan Graham,1984). Hubungan itu telah digunakan untuk menjumlahkan hubungan produktivitas dengan erosi untuk tanah-tanah karena dipengaruhi dampak erosi terhadap sifat tanah yang melekat dan proses-proses hubungannya. Penurunan produktivitas pada tanah daerah ini mungkin disebabkan penununan sifat fisik dan kimia tanah, namun belum dapat diketahui sifat fisik dan kimia mana yang paling dominan dalam mempengaruhi produktivitas tanah tersebut. Jika sifat yang paling menentukan produktivitas sudah diketahui maka dalam pengelolaan selanjutnya akan 
memudahkan kita melakukan perbaikan secara tepat dan efisien. Hasil penelitian Lal (1987) menunjukan bahwa kehilangan hasil tanaman disebabkan oleh penurunan kandungan liat, pori mikro dan ketersediaan air dalam tanah. Hukum minimum dari Liebig menyatakan bahwa hasil tanaman itu ditentukan oleh faktor yang paling lemah atau kandungan unsur hara yang paling rendah yang terdapat di dalam tanah, walaupun ada unsur hara lain mempunyai konsentrasi yang tinggi.

Sumatera Barat merupakan salah satu sentra penghasil tanaman hortikultura yang cukup berpotensial di Indonesia. namun produktivitasnya masih rendah dibandingkan dengan daerah lain. Permasalahan hasil hortikultura di Sumatera Barat adalah hasilnya rendah, kontinuitasnya tak terjamin, pada waktu tertentu hasilnya berlimpah dan pada saat dibutuhkan hasil rendah Disamping itu teknologi dan inovasi baru hasil penelitian para peneliti belum menyentuh kebutuhan petani dan pemasaran hasil masih dikuasai oleh tengkulak dan padagang pengumpul dan pedagang besar yang tidak memihak pada petani sehingga keuntungan yang diperoleh kecil dan kehidupan petani menjadi termarginalkan.

Berdasarkan uraian diatas, maka untuk daerah penelitian agar supaya dapat mengetahui faktor sifat fisik dan kimia mana yang paling dapat membatasi terhadap pertumbuhan dan hasil tanaman. maka diperlukan penelitian tentang hubungan sifat fisik dan kimia tanah dengan hasil tanaman atau produktivitas tanah di daerah ini. Dengan demikian pengelolaan lahan akan lebik tepat sasaran dan lebih efisien sehingga produktivitas tanaman dapat ditingkatkan. Disamping itu, penelitian ini juga mendukung precision farming yang mulai digalakkan untuk memenuhi hasil tanaman dan serat yang permintaannya dari tahun ke tahun sangat meningkat, dan mengkompensasikan penurunan luas lahan akibat konversi ke lahan bukan pertanian yang juga meningkat.

\section{BAHAN DAN METODA}

Tanah daerah penelitian adalah Andisol Gunung Merapi di daerah kenagarian Pandai Sikek kecamatan X Koto, Kabupaten Tanah Datar. Analisis sampel tanah dilakukan di Laboratorium Jurusan Tanah Universiotas Andalas Padang. Penelitian dilaksanakan pada Tahun 2003 sampai 2005.

Penelitian dilakukan dengan cara mensurvei daerah tersebut dan mengambil sampel tanah utuh dan sampel komposit. Penetapan lokasi pengambilan sampel dilakukan dengan menggunakan purposive random sampling pada peta lokasi penelitian yang dapat dilihat pada Gambar 1. Sampel komposit diambil dengan menggunakan bor Belgia dan sampel utuh menggunakan ring sampel pada kedalaman 0-20 cm.

Pengamatan yang dilakukan baik dari sampel utuh untuk sifat fisik tanah yakni bobot isi dengan metoda gravimetrik, permeabilitas dengan metoda De Boodt, daya pegang air pada $\mathrm{pF} 2.54$, kepadatan tanah dengan penetrometer, dan sampel komposit untuk sifat kimia tanah yakni pH tanah dengan pH meter, P-tersedia dengan metoda Bray II, C-Organik dengan metoda Walkley and Black, kation basa (Ca,Mg,K,Na) dan KTK tanah dengan pencucian Amoniun acetate $\mathrm{pH}$ 7.0, $\mathrm{N}$ total dengan alat Kjehdhall, dan lain-lain.

Pengolahan data dilakukan dengan menggunakan hubungan peubah bebas dengan peubah tidak bebas dengan memakai program Stat 2.7 (Ratno, UNPAD, 1998). 


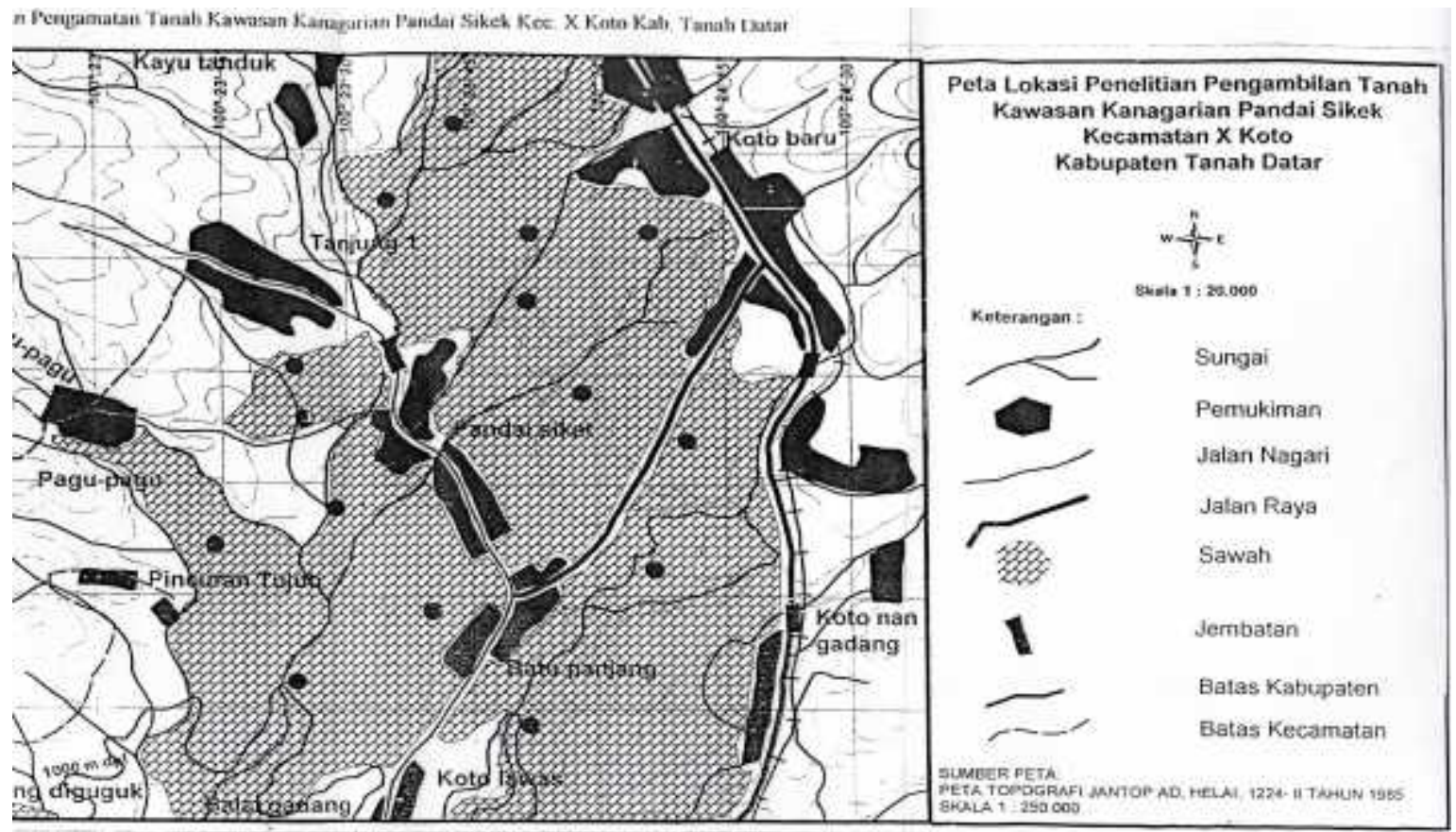

Gambar 1. Lokasi pengambilan sample tanah

\section{HASIL DAN PEMBAHASAN}

\section{Keadaan Daerah Penelitian}

Kecamatan X Koto Kabupaten Tanah Datar Propinsi Sumatera Barat terbentuk dari formasi geologi andesit gunung Merapi dan Singgalang, dan merupakan sentra tanaman hortikultura yang pemupukannya belum berdasarkan hasil analisis tanah tetapi hanya berdasarkan rekomendasi pemumupukan secara umum. Berdasarkan fisografi daerahdaerah studi, bahan induk tanah umumnya berasal dari bahan vulkanik gunung api seperti gunung Marapi dan Singgalang, yaitu bahan vulkanik tua (Qast). Curah hujan rataan 3086 mm, suhu rataan adalah $21,54{ }^{\circ} \mathrm{C}$, pada ketinggian $1200 \mathrm{~m}$ dpl. Order tanahnya umumnya adalah Andisol. Dengan demikian sifat kesuburan tanah daerah tersebut ditentukan oleh asal bahan induk tanah tersebut, serta proses-proses pembentukan tanah yang berlangsung di daerah studi tersebut. Lahan pertanaman ini pada musim hujan menjadi sawah dan pada musim kemarau menjadi tanaman sayuran. Namun sekarang karena hasil sayur sangat duibutuhkan, maka lahan ini sangat sering diusahakan untuk tanaman sayuran daripada tanaman padi.

\section{Sifat Fisik Tanah}

a. Sifat fisik tanah untuk penanaman kubis Hasil analisis sifat fisik tanah yang dilakukan pada daerah pertanaman kubis dan wortel dapat dilihat pada Tabel 1. Dari Tabel 1 dapat dilihat bahwa tanah yang dipergunakan untuk tanaman kubis memperlihatkan porositas tanah tergolong tinggi. permeabilitas tanah agak bervariasi dari sedang sampai agak cepat. C-organik tergolong tinggi. pori aerase tergolong sangat tinggi. pori drainase lambat tergolong rendah dan pori air tersedia tergolong sedang sampai tinggi. Kalau kira lihat perbandingan pori aerase dengan PAT + PDL hampir sama yang mengindikasikan tanah ini mempunyai sifat fisik yanag baik. 
Tabel 1. Sifat fisik tanah untuk lahan yang ditanami dan hasil tanaman kubis

\begin{tabular}{|c|c|c|c|c|}
\hline Kode & $\begin{array}{c}\text { Bobot isi } \\
\mathrm{g} / \mathrm{cm}^{2}\end{array}$ & TRP & $\begin{array}{c}\text { C-Org } \\
(\%)\end{array}$ & $\begin{array}{c}\text { Permebilitas } \\
\text { Cm/jam }\end{array}$ \\
\hline 1 & 0.87 & 67.17 & 6.0 ST & $14.8 \mathrm{C}$ \\
\hline 2 & 0.77 & 70.94 & 8.2 ST & $5.70 \mathrm{~S}$ \\
\hline 3 & 0.78 & 70.57 & $5.5 \mathrm{ST}$ & $4.02 \mathrm{~S}$ \\
\hline 4 & 0.61 & 76.98 & $5.8 \mathrm{ST}$ & $5.30 \mathrm{~S}$ \\
\hline 5 & 0.85 & 67.92 & $5.4 \mathrm{ST}$ & $9.50 \mathrm{AC}$ \\
\hline 6 & 0.68 & 74.31 & 6.0 ST & 14.70 C \\
\hline 7 & 0.78 & 70.94 & $7.3 \mathrm{ST}$ & $4.60 \mathrm{~S}$ \\
\hline 8 & 0.73 & 72.45 & 6.3 ST & $5.02 \mathrm{AC}$ \\
\hline 9 & 0.69 & 73.96 & 8.9 ST & $10.80 \mathrm{AC}$ \\
\hline 10 & 0.74 & 72.08 & 7.1 ST & $8.30 \mathrm{AC}$ \\
\hline 11 & 0.63 & 76.23 & 8.9 ST & 8.60 AC \\
\hline 12 & 0.85 & 67.92 & 7.8 ST & $8.40 \mathrm{AC}$ \\
\hline 13 & 0.87 & 67.17 & 6.9 ST & $8.70 \mathrm{AC}$ \\
\hline 14 & 0.79 & 70.19 & $6.4 \mathrm{ST}$ & $19.70 \mathrm{C}$ \\
\hline 15 & 0.72 & 72.83 & 6.0 ST & $11.90 \mathrm{AC}$ \\
\hline
\end{tabular}

\begin{tabular}{|c|rl|rr|rr|c|}
\hline Kode & $\begin{array}{r}\text { Pori Aerasi } \\
(\% \text { Vol })\end{array}$ & \multicolumn{2}{|c|}{$\begin{array}{c}\text { PAT } \\
(\% \text { Vol })\end{array}$} & $\begin{array}{r}\text { Pori Drainse L } \\
(\% \text { Vol })\end{array}$ & Hasil tanaman \\
\hline 1 & 20.97 & ST & 16.27 & T & 4.53 & SR & 22.40 \\
\hline 2 & 23.31 & ST & 14.78 & S & 4.54 & SR & 12.00 \\
\hline 3 & 25.77 & ST & 15.39 & S & 5.36 & R & 16.00 \\
\hline 4 & 29.55 & ST & 14.17 & S & 5.23 & R & 14.00 \\
\hline 5 & 21.64 & ST & 14.5 & S & 4.63 & SR & 12.00 \\
\hline 6 & 27.13 & ST & 14.19 & S & 4.51 & SR & 18.00 \\
\hline 7 & 20.05 & ST & 15.91 & T & 5.91 & R & 29.00 \\
\hline 8 & 22.36 & ST & 16.43 & T & 4.75 & SR & 17.20 \\
\hline 9 & 23.67 & ST & 15.22 & T & 4.81 & SR & 18.40 \\
\hline 10 & 25.55 & ST & 14.54 & S & 4.56 & SR & 17.60 \\
\hline 11 & 28.18 & ST & 14.69 & S & 4.93 & SR & 18.00 \\
\hline 12 & 17.23 & ST & 16.01 & T & 5.71 & R & 12.00 \\
\hline 13 & 21.95 & ST & 13.87 & S & 4.27 & SR & 20.00 \\
\hline 14 & 26.68 & ST & 13.55 & S & 4.16 & SR & 19.20 \\
\hline 15 & 27.07 & ST & 14.16 & S & 4.58 & SR & 16.00 \\
\hline
\end{tabular}

b. Sifat Fisik Tanah untuk Penanaman Wortel

Hasil analisis sifat fisik tanah yang dilakukan pada daerah pertanaman wortel dapat dilihat pada Tabel 2. Dari Tabel 2 dapat dilihat bahwa tanah yang dipergunakan untuk tanaman wortel memperlihatkan porositas tanah tergolong tinggi. permeabilitas tanah agak bervariasi dari sedang sampai agak cepat. C-organik tergolong sangat tinggi. pori aerase tergolong tinggi. pori drainase lambat tergolong rendah dan pori air tersedia tergolong sedang sampai tinggi. namun kalau dilihat perbandingan pori aerasi dan pori tersedia air dan PDL yaitu adalah mendekati 1:1 . jadi tanah ini dikatakan mempunyai sifat fisik yang baik. Sifat fisik tanah vulkanis ini telah dilaporkan mempunyai sifat fisik yang lebih baik 
Tabel 2. Sifat fisik tanah yang ditanami dengan wortel

\begin{tabular}{|c|c|c|c|c|}
\hline Kode & $\begin{array}{c}\text { Bobot isi } \\
\text { g/cm }\end{array}$ & $\begin{array}{l}\text { TRP } \\
(\%)\end{array}$ & $\begin{array}{c}\text { C-Org } \\
(\%)\end{array}$ & $\begin{array}{c}\text { Permebilitas } \\
\text { (Cm/jam) }\end{array}$ \\
\hline 1 & 0.69 & 73.96 & $\begin{array}{ll}6.30 & \text { ST }\end{array}$ & $5.40 \quad \mathrm{~S}$ \\
\hline 2 & 0.74 & 72.08 & $7.10 \quad$ ST & $5.60 \mathrm{~S}$ \\
\hline 3 & 0.66 & 75.09 & $\begin{array}{ll}5.70 & \text { ST } \\
\end{array}$ & $3.80 \mathrm{~S}$ \\
\hline 4 & 0.62 & 76.60 & $\begin{array}{ll}5.50 & \text { ST }\end{array}$ & $7.60 \quad \mathrm{AC}$ \\
\hline 5 & 0.69 & 73.96 & $\begin{array}{ll}5.30 & \text { ST }\end{array}$ & $11.50 \quad A C$ \\
\hline 6 & 0.73 & 72.45 & $\begin{array}{ll}5.80 & \text { ST }\end{array}$ & $\begin{array}{rl}2.70 & S\end{array}$ \\
\hline 7 & 0.71 & 73.21 & $\begin{array}{ll}.10 & \text { ST } \\
\end{array}$ & $3.40 \quad \mathrm{~S}$ \\
\hline 8 & 0.80 & 69.81 & $\begin{array}{ll}7.00 & \text { ST } \\
\end{array}$ & $17.90 \quad$ AC \\
\hline 9 & 0.73 & 72.45 & $\begin{array}{ll}6.50 & \mathrm{ST}\end{array}$ & $10.30 \quad A C$ \\
\hline 10 & 0.71 & 73.21 & $7.20 \quad$ ST & $5.70 \mathrm{~S}$ \\
\hline 11 & 0.70 & 73.58 & $9.00 \quad \mathrm{ST}$ & $9.30 \quad \mathrm{AC}$ \\
\hline 12 & 0.82 & 69.09 & $\begin{array}{ll}7.40 & \text { ST }\end{array}$ & $7.90 \quad \mathrm{AC}$ \\
\hline 13 & 0.68 & 74.34 & $6.60 \quad \mathrm{ST}$ & $12.90 \mathrm{C}$ \\
\hline 14 & 0.75 & 71.70 & $6.50 \quad \mathrm{ST}$ & $19.40 \mathrm{C}$ \\
\hline 15 & 0.77 & $70 . .94$ & $\begin{array}{ll}7.30 & \mathrm{ST}\end{array}$ & $5.90 \mathrm{~S}$ \\
\hline
\end{tabular}

\begin{tabular}{|c|c|c|c|c|}
\hline Kode & $\begin{array}{c}\text { PA } \\
(\% \text { Vol })\end{array}$ & $\begin{array}{c}\text { PAT } \\
(\% \text { Vol })\end{array}$ & $\begin{array}{c}\text { PDL } \\
(\% \text { Vol })\end{array}$ & Hasil tanaman \\
\hline 1 & $21.60 \mathrm{ST}$ & 15.22 T & $5.18 \quad R$ & 5.60 \\
\hline 2 & 24.47 ST & $14.94 \mathrm{~T}$ & $5.04 \quad R$ & 8.00 \\
\hline 3 & 25.01 ST & $\begin{array}{ll}15.77 & T \\
\end{array}$ & $\begin{array}{ll}5.69 & R \\
\end{array}$ & 7.60 \\
\hline 4 & 24.74 ST & $\begin{array}{ll}15.83 & T \\
\end{array}$ & $\begin{array}{ll}4.73 & \text { SR }\end{array}$ & 8.00 \\
\hline 5 & 41.03 ST & $11.03 \quad T$ & $\begin{array}{ll}3.60 & \text { SR }\end{array}$ & 8.00 \\
\hline 6 & 21.05 ST & $\begin{array}{ll}15.67 & \text { ST } \\
\end{array}$ & $5.42 \quad \mathrm{R}$ & 5.60 \\
\hline 7 & 30.52 ST & $14.08 \mathrm{~T}$ & 4.60 $\quad$ SR & 12.00 \\
\hline 8 & 23.26 ST & $14.62 \mathrm{~S}$ & $\begin{array}{ll}4.88 & \text { SR } \\
\end{array}$ & 8.00 \\
\hline 9 & 22.59 ST & $14.60 \mathrm{~S}$ & 4.76 $\quad$ SR & 8.00 \\
\hline 10 & 24.08 ST & $15.45 \mathrm{~T}$ & 5.25 & 7.36 \\
\hline 11 & 23.43 ST & $15.04 \quad T$ & $\begin{array}{ll}4.76 & \text { SR } \\
\end{array}$ & 7.20 \\
\hline 12 & 20.03 ST & $\begin{array}{ll}15.75 & T \\
\end{array}$ & $\begin{array}{ll}5.09 & R \\
\end{array}$ & 8.00 \\
\hline 13 & 26.79 ST & $14.17 \mathrm{~S}$ & 4.65 $\quad$ SR & 8.00 \\
\hline 14 & 19.45 ST & $16.16 \mathrm{~T}$ & $\begin{array}{ll}5.22 & \text { R } \\
\end{array}$ & 5.60 \\
\hline 15 & 29.39 ST & $14.45 \mathrm{~S}$ & $\begin{array}{ll}5.60 & \text { R } \\
\end{array}$ & 8.00 \\
\hline
\end{tabular}

\section{Sifat Kimia Tanah}

a. Sifat kimia tanah yang dtanami dengan tanaman kubiss
Bedasarkan hasil analisis tanah di laboratorium dan dibandingkan dengan kritian sifat kimia tanah maka sifat kimia tanah di daerah dapat ditambilkan pada Tabel 3 untuk tanaman kubis 
Tabel 3. Sifat kimia tanah yang ditanami dengan tanaman kubis

\begin{tabular}{|c|c|c|c|c|c|c|}
\hline Kode & pH & KTK & P-tersedia & C-organik & KB & N-Total \\
\hline 1 & 5.17 M & $16.23 \mathrm{R}$ & 20.59 S & $3.46 \mathrm{~T}$ & $60.68 \mathrm{~T}$ & $0.11 R$ \\
\hline 2 & 4.29 M & $15.29 R$ & $\begin{array}{ll}42.60 & \mathrm{ST}\end{array}$ & $4.75 \mathrm{~T}$ & $48.97 \mathrm{~S}$ & $0.12 R$ \\
\hline 3 & $5.05 \quad M$ & $17.05 \mathrm{~S}$ & $20.03 \mathrm{~S}$ & $3.17 \quad \mathrm{~T}$ & $60.55 \mathrm{~T}$ & $0.14 R$ \\
\hline 4 & $5.03 \quad M$ & $12.50 \mathrm{R}$ & $19.16 \mathrm{~S}$ & $\begin{array}{ll}3.37 & \text { T } \\
\end{array}$ & $\begin{array}{ll}69.56 & T \\
\end{array}$ & $\begin{array}{ll}\mathbf{0 . 0 7} & \text { SR } \\
\end{array}$ \\
\hline 5 & $4.50 \mathrm{M}$ & $13.47 \mathrm{R}$ & $34.14 \quad T$ & $3.13 \mathrm{~T}$ & $66.16 \mathrm{~T}$ & 0.08 SR \\
\hline 6 & $4.72 \mathrm{M}$ & $14.13 \mathrm{R}$ & $34.14 \quad \mathrm{~T}$ & $3.46 \mathrm{~T}$ & $\begin{array}{ll}56.48 & T\end{array}$ & $\begin{array}{ll}\text { 0.07 } & \text { SR }\end{array}$ \\
\hline 7 & $4.65 \mathrm{M}$ & $16.48 \mathrm{~S}$ & $\begin{array}{ll}36.30 & \text { ST } \\
\end{array}$ & $4.26 \quad T$ & $67.62 \mathrm{~T}$ & $0.16 R$ \\
\hline 8 & $4.97 \mathrm{M}$ & $17.12 \mathrm{~S}$ & 47.94 ST & $3.65 \mathrm{~T}$ & $\begin{array}{ll}59.47 & \text { T }\end{array}$ & $0.11 R$ \\
\hline 9 & 4.04 SM & $13.38 R$ & $\begin{array}{ll}29.38 & T\end{array}$ & 5.21 ST & $\begin{array}{ll}59.90 & \text { T }\end{array}$ & $0.11 R$ \\
\hline 10 & 4.41 SM & $13.04 R$ & $16.23 \mathrm{~S}$ & $4.13 \mathrm{~T}$ & $63.20 \mathrm{~T}$ & $0.15 R$ \\
\hline 11 & $5.24 \mathrm{M}$ & $16.31 R$ & $16.30 \mathrm{~S}$ & 5.15 ST & $56.46 \mathrm{~T}$ & $0.11 R$ \\
\hline 12 & $5.10 \mathrm{M}$ & $16.61 R$ & 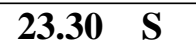 & $4.54 \quad T$ & $\begin{array}{ll}64.67 & T\end{array}$ & $\begin{array}{ll}0.03 & \text { SR }\end{array}$ \\
\hline 13 & $4.62 \mathrm{M}$ & $15.08 R$ & $19.05 \mathrm{~S}$ & $4.03 \mathrm{~T}$ & $64.12 \mathrm{~T}$ & $\begin{array}{ll}0.03 & \text { SR }\end{array}$ \\
\hline 14 & $4.69 \mathrm{M}$ & $16.31 R$ & 41.02 ST & $3.73 \mathrm{~T}$ & 63.27 T & 0.11 R \\
\hline 15 & 4.10 SM & $16.90 R$ & $18.95 \mathrm{~S}$ & $3.49 \mathrm{~T}$ & $\begin{array}{ll}50.04 & T\end{array}$ & $0.11 R$ \\
\hline
\end{tabular}

\begin{tabular}{|c|c|c|c|c|c|}
\hline Kode & Ca & Mg & $\mathbf{K}$ & $\mathrm{Na}$ & Hasil tanaman \\
\hline 1 & $2.45 R$ & $3.30 \mathrm{~T}$ & $0.15 \mathrm{R}$ & 3.96 ST & 22.40 \\
\hline 2 & 1.33 SR & $2.28 \mathrm{~T}$ & $0.13 \mathrm{R}$ & 3.74 ST & 12.00 \\
\hline 3 & $2.91 \mathrm{R}$ & $3.18 \mathrm{~T}$ & $0.17 \mathrm{R}$ & 4.07 ST & 16.00 \\
\hline 4 & $2.61 R$ & $1.91 \mathrm{~S}$ & $0.15 \mathrm{R}$ & 4.02 ST & 14.00 \\
\hline 5 & 1.85 SR & $2.55 \mathrm{~T}$ & $0.20 \mathrm{R}$ & 4.31 ST & 12.00 \\
\hline 6 & 1.41 SR & $1.88 \mathrm{~S}$ & $0.16 \mathrm{R}$ & $4.53 \mathrm{ST}$ & 18.00 \\
\hline 7 & $3.49 R$ & $2.83 \mathrm{~T}$ & $0.16 \mathrm{R}$ & $4.66 \mathrm{ST}$ & 29.00 \\
\hline 8 & 1.84 SR & $2.35 \mathrm{~T}$ & $0.24 \mathrm{R}$ & $5.75 \mathrm{ST}$ & 17.20 \\
\hline 9 & 1.24 SR & $1.68 \mathrm{~S}$ & $0.24 \mathrm{R}$ & 4.84 ST & 18.40 \\
\hline 10 & $2.06 R$ & $2.04 \mathrm{~T}$ & $0.15 \mathrm{R}$ & 3.99 ST & 17.60 \\
\hline 11 & 1.74 SR & $1.88 \mathrm{~S}$ & $0.25 \mathrm{R}$ & $5.34 \mathrm{ST}$ & 18.00 \\
\hline 12 & $2.64 \mathrm{R}$ & $2.70 \mathrm{~T}$ & $0.24 \mathrm{R}$ & $5.16 \mathrm{ST}$ & 12.00 \\
\hline 13 & $2.48 \mathrm{R}$ & $2.60 \mathrm{~T}$ & $0.21 \mathrm{R}$ & $4.38 \mathrm{ST}$ & 20.00 \\
\hline 14 & $2.86 \quad R$ & $2.74 \mathrm{~T}$ & $0.19 \mathrm{R}$ & 4.71 ST & 19.20 \\
\hline 15 & 1.89 SR & $2.03 \mathrm{~T}$ & $0.15 \mathrm{R}$ & $4.39 \mathrm{ST}$ & 16.00 \\
\hline
\end{tabular}

Dari Tabel 3 dapat dilihat bahwa pH tanah umunya sangat masam sampai agak masam untuk kedua tanaman kubis dan wortel. KTK umumnya rendah sampai sedang. P-tersedia berkisar dari sedang sampai tinggi. kejenuhan basa umumnya sangat tinggi. N-total umumnya sangat rendah sampai rendah. Ca dapat ditukar tergolong sangat rendah sampai rendah. Md daspat ditukar tergolong sedang sampai tinggi. $K$ dapat ditukar tergolong rendah. dan Na dapat ditukar tergolong sangat tinggi.

b. Sifat Kimia Tanah Yang Ditanami Dengan Tanaman Wortel

Bedasarkan hasil analisis tanah di laboratorium dan dibandingkan dengan kritian sifat kimia tanah maka sifat kimia tanah di daerah untuk tanaman wortel dapat ditambilkan pada Tabel 4. 
Tabel 4. Sifat kimia tanah yang ditanami dengan tanaman wortel

\begin{tabular}{|c|c|c|c|c|c|c|}
\hline Kode & pH & KTK & P-tersedia & C-organik & KB & N-Total \\
\hline 1 & 4.07 SM & 14.11 R & $26.35 \mathrm{~T}$ & $3.68 \mathrm{~T}$ & $56.61 \mathrm{~T}$ & 0.11R \\
\hline 2 & $4.66 \mathrm{M}$ & 16.83 R & 48.31 ST & $4.14 \mathrm{~T}$ & 61.21T & $0.18 \mathrm{R}$ \\
\hline 3 & $4.73 \mathrm{M}$ & 14.29 R & $50.70 \mathrm{ST}$ & $3.29 \mathrm{~T}$ & $62.60 \mathrm{~T}$ & 0.14R \\
\hline 4 & $5.53 \mathrm{M}$ & $13.94 R$ & $17.05 \mathrm{~S}$ & $3.21 \mathrm{~T}$ & 69.11T & 0.08SR \\
\hline 5 & $5.02 \mathrm{M}$ & 15.27 R & $29.16 \mathrm{~T}$ & $4.14 \mathrm{~T}$ & $69.83 \mathrm{~T}$ & 0.07SR \\
\hline 6 & 4.12 SM & 13.57 R & 49.30 ST & $3.36 \mathrm{~T}$ & 53.79T & 0.14R \\
\hline 7 & $4.13 \mathrm{SM}$ & $17.45 \mathrm{~S}$ & 45.81 ST & $4.08 \mathrm{~T}$ & $62.18 \mathrm{~T}$ & $0.17 \mathrm{R}$ \\
\hline 8 & $4.79 \mathrm{M}$ & $17.18 \mathrm{~S}$ & 27.85 T & $4.08 \mathrm{~T}$ & $62.18 \mathrm{~T}$ & 0.05 SR \\
\hline 9 & $4.33 \mathrm{SM}$ & $17.05 \mathrm{~S}$ & $22.24 \mathrm{~S}$ & 6.08 ST & $59.44 \mathrm{~T}$ & $0.15 R$ \\
\hline 10 & $4.61 \mathrm{M}$ & 13.05 R & $20.51 \mathrm{~S}$ & $4.20 \mathrm{~T}$ & $62.47 \mathrm{~T}$ & $0.11 R$ \\
\hline 11 & $4.94 \mathrm{M}$ & $17.05 \mathrm{~S}$ & $28.08 \mathrm{~S}$ & $4.69 \mathrm{~T}$ & $59.86 \mathrm{~T}$ & $0.14 R$ \\
\hline 12 & $4.82 \mathrm{M}$ & 18.66 S & $18.70 \mathrm{~S}$ & $4.34 \mathrm{~T}$ & $59.89 \mathrm{~T}$ & 0.04 SR \\
\hline 13 & $4.88 \mathrm{M}$ & $15.73 \mathrm{R}$ & $\begin{array}{ll}33.00 & T \\
\end{array}$ & $3.83 \mathrm{~T}$ & 59.87 T & $0.11 R$ \\
\hline 14 & $5.62 \mathrm{AM}$ & 15.50 R & $23.86 \mathrm{~S}$ & $3.80 \mathrm{~T}$ & $68.25 \mathrm{~T}$ & 0.07 SR \\
\hline 15 & $5.85 \mathrm{M}$ & $19.71 \mathrm{~S}$ & $\begin{array}{ll}28.17 & T \\
\end{array}$ & $\begin{array}{ll}4.25 & \mathrm{~T} \\
\end{array}$ & $64.79 \mathrm{~T}$ & 0.15 R \\
\hline
\end{tabular}

\begin{tabular}{|c|c|c|c|c|c|}
\hline Kode & $\mathbf{C a}$ & $\mathrm{Mg}$ & $\mathbf{K}$ & $\mathbf{N a}$ & Hasil tanaman \\
\hline 1 & $1.78 \mathrm{SR}$ & $2.47 \mathrm{~T}$ & 0.16 R & $3.56 \mathrm{ST}$ & 5.60 \\
\hline 2 & $3.08 \mathrm{R}$ & $2.39 \mathrm{~T}$ & $0.18 \mathrm{R}$ & $4.65 \mathrm{ST}$ & 8.00 \\
\hline 3 & 1.97 SR & $2.42 \mathrm{~T}$ & 0.17 R & $4.38 \mathrm{ST}$ & 7.60 \\
\hline 4 & $2.69 \mathrm{R}$ & $2.61 \mathrm{~T}$ & 0.17 R & 4.17 ST & 8.00 \\
\hline 5 & $2.77 \mathrm{R}$ & $2.91 \mathrm{~T}$ & $0.18 \mathrm{R}$ & 4.80 ST & 8.00 \\
\hline 6 & $1.12 \mathrm{SR}$ & $1.82 \mathrm{~S}$ & $0.13 \mathrm{R}$ & $4.22 \mathrm{ST}$ & 5.60 \\
\hline 7 & $1.58 \mathrm{SR}$ & $2.09 \mathrm{~T}$ & $0.19 \mathrm{R}$ & 5.07 ST & 12.00 \\
\hline 8 & $2.34 \mathrm{R}$ & $2.68 \mathrm{~T}$ & 0.21 R & $5.62 \mathrm{ST}$ & 8.00 \\
\hline 9 & $2.42 \mathrm{R}$ & $2.38 \mathrm{~T}$ & $0.29 \mathrm{R}$ & $5.05 \mathrm{ST}$ & 8.00 \\
\hline 10 & 1.62 SR & $2.09 \mathrm{~T}$ & 0.19 R & $4.24 \mathrm{ST}$ & 7.36 \\
\hline 11 & $3.11 \mathrm{R}$ & $2.85 \mathrm{~T}$ & $0.18 \mathrm{R}$ & 4.07 ST & 7.20 \\
\hline 12 & $2.83 \mathrm{R}$ & $2.36 \mathrm{~T}$ & $0.26 \mathrm{R}$ & $5.73 \mathrm{ST}$ & 8.00 \\
\hline 13 & $2.23 \mathrm{R}$ & $2.34 \mathrm{~T}$ & $0.21 \mathrm{R}$ & 4.65 ST & 8.00 \\
\hline 14 & $3.41 \mathrm{R}$ & $2.76 \mathrm{~T}$ & $0.24 \mathrm{R}$ & $4.16 \mathrm{ST}$ & 5.60 \\
\hline 15 & $3.40 \mathrm{R}$ & $3.13 \mathrm{~T}$ & $0.25 \mathrm{R}$ & $5.98 \mathrm{ST}$ & 8.00 \\
\hline
\end{tabular}

Dari Tabel 4 dapat dilihat bahwa pH tanah umunya sangat masam sampai agak masam untuk kedua tanaman kubis dan wortel. KTK umumnya rendah sampai sedang. Ptersedia berkisar dari sedang sampai tinggi. kejenuhan basa umumnya sangat tinggi. N- total umumnya sangat rendah sampai rendah. Ca dapat ditukar tergolong sangat rendah sampai rendah. Md dapat ditukar tergolong umumnya tinggi. $\mathrm{K}$ dapat ditukar tergolong rendah. dan Na dapat ditukar tergolong sangat tinggi. 


\section{Hubungan Sifat fisik dan kimia tanah dengan hasil tanaman}

a. Hubungan sifat fisik tanah dengan hasil tanaman kubis

Tabel 5. Hubungan sifat fisika tanah dengan hasil tanaman

\begin{tabular}{l|c|l|c}
\hline Tanaman & Persamaan Regressi berganda & $\mathbf{R}^{2}$ & $\mathrm{r}$ \\
\hline Kubis & $\mathrm{Y}=\mathbf{- 5 1 7 1 . 4 4}-\mathbf{1 9 6 3} \mathrm{BV}+\mathbf{5 2 . 1 0} \mathrm{TRP}+\mathbf{4 . 7 7}$ PDL & $\mathbf{0 . 7 5}$ & $\mathbf{0 . 8 7}$ \\
Wortel & $\mathrm{Y}=\mathbf{- 2 . 2 8}+\mathbf{0 . 7 1} \mathrm{C}-$ Org + 0.17 PA & $\mathbf{0 . 4 3}$ & $\mathbf{0 . 6 6}$ \\
\hline
\end{tabular}

Dengan menggunakan regresi langkah mundur (backward step regression method ) hubungan antara hasil tanaman dengan sifat fisik tanah untuk tanaman kubis diperoleh persamaan sebagai terlihat pada Tabel 5 .

Dari Tabel 5 dapat dilihat bahwa diantara peubah peubah sifat fisik tanah yang telah diuraikan diatas yang dapat mempengaruhi hasil tanaman kubis adalah bobot isi, total nung pori dan pori drainase lambat. Sedangkan untuk hasil wortel ditentukan oleh C-organik dan pori aerasi tanah. Hal ini dapat dijelaskan bahwa tanaman wortel merupakan tanaman umbi yang terletak di dalam tanah, maka pori aerasi sangat respon terhadap hasil tanaman. Menurut Winters dan Samonson (1950) kepadatan tanah yang tinggi, kejenuhan Al tinggi, pH rendah. Kapasitas pemegang air bagi tanaman berkurang, kadar liat meningkat, dan zona perakaran berkurang karena adanya batuan adalah sebagai factor yang membatasi hasil diluar yang dikompensasikan dengan penambahan pupuk.

b. Hubungan sifat kimia tanah dengan hasil tanaman

Dengan menggunakan regresi langkah mundur (backward step regression method ) hubungan antara hasil tanaman dengan sifat kimia tanah untuk tanaman kubis dan tanaman wortel diperoleh persamaan sebagai terlihat pada Tabel 6.

Dari Tabel 6 dapat dilihat bahwa tanaman kubis sangat respon terhadap peningkatan unsur Nitrogen dan calsium. Sedangkan tanaman wortel respon terhadap peningkatan kapasitas tukar kation, kejenuhan basa, dan peningkatan kalsium tanah.

Tabel 6. Hubungan sifat kimia tanah dengan hasil tanaman

\begin{tabular}{l|c|l|c}
\hline Tanaman & Persamaan Regressi berganda & $R^{2}$ & \multicolumn{1}{c}{} \\
\hline Kubis & $Y=-6.87+42.99 \mathrm{~N}+\mathbf{2 . 8 6} \mathrm{Ca}$ & 0.36 & 0.59 \\
\hline Wortel & $\mathrm{Y}=-\mathbf{1 6 . 5 1}+\mathbf{0 . 8 4} \mathrm{KTK}+\mathbf{0 . 2 8} \mathrm{KB}+\mathbf{2 . 3 8} \mathrm{Ca}$ & 0.71 & 0.84 \\
\hline
\end{tabular}




\section{KESIMPULAN DAN SARAN}

Kesimpulan

1. Tanah yang ditanami dengan kubis dan wortel mempunyasi sifat fisik tanah yang baik seperti yang terlihat dari perbandingan ruang pori aerase dan ruang pori yang diisi air.

2. Tanah yang ditanmi dengan kubis dan wortel sifat kimia mempunyai kandungan yang cukup kecuali unsur hara $\mathbf{N}$ dan . K dan $\mathrm{Ca}$ dapat ditukar yang tergolong sangat rendah. sedangkan sifat-sifat lain cukup baik.

3. Hubungan sifat fisik tanah dengan kedua tanaman agak berbeda tergantung kepada jenis tanamannya. kalau tanaman berumbi seprti wortel akan renspon terhadap pori aerase tanah. dan kandungan bahan organik tanah. sedangkan tanaman kubis lebih respon terhadap perobahan bobot isi. total rung pori dan pori drainase lambat.

4. Hubungan sifat kimia dengan hasil tanaman tidak terlalu berbeda karena sama sama respon terhadap kandungan Ca. namun untuk tanaman kubis juga lebih respon terhadap kandungan $\mathrm{N}$ total. tetapi wortel juga lebih respon terhadap Kapasitas Tukar Kation dan Kejenuhan basa.

\section{Saran-Saran}

Sesuai dengan apa yang ditampilkan pada kesimpulan diatas maka dapat disarankan bahwa:

1. Untuk usahatani tanaman kubis dan wortel agar dapat berhasil dengan baik maka perlu dicarikan tanah gembur

2. Pengusahaan tanaman kubis dan wortel di daerah ini sebaiknya diberikan sedikit kapur agar supaya dapat nmeningkatkan $\mathrm{pH}$ tanah dan memenuhi kebutuhan unsur hara $\mathrm{Ca}$ dapat dilakukan. dismping itu perlu diberikan sejunlah unsur hara $\mathbf{N}$ karena unsur $\mathbf{N}$ tanah rendah.

Daftar Pustaka
Ableiter. J. K. 1937. Productivity ratings in the soil surm report. Soil Science Society of America Proceedings: 415427.

Dedi Hermon. 2001. Studi Kontribusi Penggunaan Lahan dan Vegetasi Terhadap Karakteristik Epipedon. Tesis Magister. Program Pascasarjana Universitas Andalas Padang.

Dinas Pertanian Tanaman Pangan dan Perkebunan Sumbar dan Pusat Kajian Pengembangan Lahan dan Pemukiman Unand Padang. 2001. Survey Investigasi dan Desain Agribisnis Hortukultura Sumatera Barat. Pusat Kajian Pengembangan Lahan dan Pemukiman Unand Padang.

Efendi. 2002. Studi Penyebaran Fosfat Anorganik dan Organik Pada Zona Perakaran Tanah Abu Vulkanik Di Kawasan Sentra Produksi Hortukultura Pada Formasi Sunggalang dan Marapi. Tesis Magister. Program Pascasarjana Universitas Andalas Padang.

Kiniry. L. N.. C. L. Scrivner. and M. E. Keener. 1983. A soil productivity index based upon predicted water depletion and root growth. Research Bulletin 1051. Missouri Agricultural Experiment Station. Columbia

Lal. $R$ dan F.J.Pierce. 1991. Soil Manajement for Sustainability. Wordd Soil Conservation Society and the Soil Science Society of America. Ankeny. Iowa.

Nelson. et al. 1963. Detailed land classification-island of Ohau. Land Study Bureau Bulletin 3. University of Hawai. Honolulu. 141 pp.

Nur Indah K. 2005. Hubungan sifat kimia tanah sawah dengan inigasi ponpanisasi V Sumani Solok dengan Hasil tanaman padi sawah. Skripsi Fakultas Pertanian Unand Padang. 
Pierce. F. J.. W. E. Larson. R. H. Dowdy. and W.A.P. Graham. 1983. Productivity of soils: Assessing longterm changes due to erosion. Joumal of Soil and Water Conservation 38: 39-44.

Riquier. J. 1977. Philosophy of the world assessment of soil degradation and items for discussion. In Food and Agriculture Organization Assessing Soil Degradation. Soils Bulletin. Food and Agriculture Organization. Rome. Italy. pp. 36-38.
Saidi. A., Asmar, dan Dian Novita. 2005. Hubungan sifat fisik tanah dengan hasil tanaman Kol di Sentra Produksi Hortikultura Kecamatan Lembah Gumanti Kabupaten Solok. Laporan Penelitian SP4. Jurusan Tanah Fakultas Pertanian Unand.

Lal. R. 1987. Effects of soil erosion on crop productivity. CRC Critical Reviews in Plant Sciences 5(4): 303-367. 